\title{
BMJ Open What can we learn on public accountability from non-health disciplines: a meta-narrative review
}

\author{
Sara Van Belle, ${ }^{1}$ Susannah H Mayhew ${ }^{2}$
}

To cite: Van Belle S, Mayhew SH. What can we learn on public accountability from non-health disciplines: a meta-narrative review. BMJ Open 2016;6:e010425. doi:10.1136/bmjopen-2015010425

- Prepublication history for this paper is available online. To view these files please visit the journal online (http://dx.doi.org/10.1136/ bmjopen-2015-010425).

Received 12 November 2015 Revised 20 April 2016 Accepted 18 May 2016

\section{CrossMark}

\author{
${ }^{1}$ Health Policy Unit, \\ Department of Public Health, \\ Institute of Tropical Medicine, \\ Antwerp, Belgium \\ ${ }^{2}$ Politics and Policy Group, \\ Faculty of Public Health and \\ Policy, London School of \\ Hygiene and Tropical \\ Medicine, London, UK
}

Correspondence to Dr Sara Van Belle; svanbelle@itg.be

\section{ABSTRACT}

Objective: In health, accountability has since long been acknowledged as a central issue, but it remains an elusive concept. The literature on accountability spans various disciplines and research traditions, with differing interpretations. There has been little transfer of ideas and concepts from other disciplines to public health and global health. In the frame of a study of accountability of (international) non-governmental organisations in local health systems, we carried out a meta-narrative review to address this gap. Our research questions were: (1) What are the main approaches to accountability in the selected research traditions? (2) How is accountability defined? (3) Which current accountability approaches are relevant for the organisation and regulation of local health systems and its multiple actors?

Setting: The search covered peer-reviewed journals, monographs and readers published between 1992 and 2012 from political science, public administration, organisational sociology, ethics and development studies. 34 papers were selected and analysed.

Results: Our review confirms the wide range of approaches to the conceptualisation of accountability. The definition of accountability used by the authors allows the categorisation of these approaches into four groups: the institutionalist, rights-based, individual choice and collective action group. These four approaches can be considered to be complementary. Conclusions: We argue that in order to effectively achieve public accountability, accountability strategies are to be complementary and synergistic.

\section{BACKGROUND}

In health policy and systems scholarship, accountability has since long been acknowledged as a central dimension. It is at the core of healthcare professionalism ${ }^{1}$ and community participation in health systems, ${ }^{2-6}$ as well as of governance. ${ }^{78}$ Many health system (performance) frameworks include accountability as part of the leadership and governance function $^{9-16}$. A closer look at the public health literature shows us that accountability emerges under (at least) four major themes.

\section{Strengths and limitations of this study}

- This is the first meta-narrative review of the concept of accountability in the disciplines of political science, public administration, organisational sociology, ethics and development studies, summarising knowledge with a view to improving public and private-non-profit sector health service management and service delivery.

- Our meta-narrative review fits the research objectives well, given the wealth of differing interpretations in the literature on accountability (across disciplines).

- Monographs and readers constituted a primary reference source. Since there is no specific book database covering monographies and readers in the disciplines included here, the review could not be entirely comprehensive.

- On the basis of the results, we propose a multidimensional framework of accountability that covers the dimensions of professional, organisational, social and political accountability.

First, accountability has been related to strategies to ensure quality of care. Clinical audits, for instance, are often used in efforts to reduce maternal mortality and near miss events and are framed in terms of negotiating accountability with health service providers. ${ }^{17-21}$ Second, accountability has been part of 'community participation', framed recently as strengthening the community's voice in order to improve accountability in health service delivery. ${ }^{22}$ The effects of decentralisation on participation were explored by Bossert and Mitchell. ${ }^{23}$ Third, accountability is a major theme in global health policy. Interest in tracking funding in order to improve 'donor accountability' has seen an upsurge, especially in maternal, neonatal and child health. ${ }^{13}{ }^{24-27}$ Finally, accountability is framed in the ethics and human rights perspective. Daniels, ${ }^{28}$ for example, focused on procedural mechanisms for accountability in a health system priority setting. Human rights advocates focus on 
accountability in relation to healthcare and health policy, including the obligation of states to ensure the right to health and improving equity in access. Recently, the UN resolution on Universal Health Coverage argued that efforts to improve universal health coverage could only succeed if values such as transparency, equity and fairness are at the basis of decision-making. This should be supported by efforts to build accountability capability and fairness in process and results. ${ }^{15} 29$

In the public health literature, strategies to improve accountability have been described at the macrolevel of global governance and policymaking, the mesolevel of health system management, participative decisionmaking and priority setting, as well as at the microlevel of service delivery, where it is considered part of professional ethics and an element of quality of care.

While the concept of accountability is widely used in the public health literature, it remains an opaque concept. To start, it is not easy to differentiate between accountability and related concepts such as responsibility and responsiveness. Moreover, the literature on accountability in fact derives from different disciplines and research traditions. "Many authors have been writing about accountability in a variety of contexts but there has been little agreement, or even common ground for disagreement, over the general nature of accountability or its various mechanisms'. ${ }^{30}$

Most authors do tend to agree, however, on the most basic of definitions. Accountability is a derivative of 'being accountable', a quality or state of being where one accepts-or is obliged to accept-responsibility for one's actions (or inactions) towards another. ${ }^{31}$ It thus presupposes a relationship between two actors where one actor (the agent or duty bearer) has to account for his actions to another actor (the principal or claims holder), because the actions of the agent affect the principal or because they have been carried out on behalf of the principal.

Although some authors in the field of public health draw on concepts from other disciplines, there has been little systematic exploration of how accountability is treated in disciplines such as political science, public administration, organisational sociology, ethics and development studies. As a result, there has been little crossfertilisation between these disciplines and public health.

To address this gap, we set out to identify the main schools of accountability across disciplines and to trace the current developments and debates. More specifically, we aimed at identifying the range of definitions of accountability and the frameworks that are being used in these different disciplines with the aim of countering the fragmentation on accountability-identified by Mulgan $^{30}$ as a major problem. We also intended this review to inform the development of a comprehensive view on accountability in healthcare. In order to do so, we adopted the meta-narrative review method.

This review was part of a doctoral research project on public accountability in public health service delivery, in which we adopted the definition of Mulgan: 'Public accountability is the obligation or moral imperative of public institutions and private-not-profit institutions involved in health service delivery to answer questions regarding their decisions and actions to the public, which is the source of their mandate, authority and legitimacy'. ${ }^{30}$

Below, we present the methodology of the metanarrative review, provide an overview of the main findings and present some issues for discussion, including a multidimensional framework of public accountability.

\section{METHODS}

The discussion of accountability as a concept and as an intervention is dispersed among different disciplines and fields. Theory mining in other relevant research traditions is therefore a good starting point in developing an understanding of accountability in health. Methodologically, the meta-narrative review is most appropriate in such cases, as it allows one to map concepts and definitions across research traditions, to trace the evolution over time and to identify any overarching conceptual approaches. ${ }^{32}$ We applied the metatriangulation principles described by Lewis and Grimes $^{33}$ to further improve the quality of the review and followed the guidance developed by Wong et $\mathrm{al}^{34}$

Both the meta-narrative review and meta-triangulation are geared towards learning from different research traditions and use paradigms as heuristics to build a richer, more comprehensive picture of a complex topic area. Paradigms can be defined as 'tightly coupled ideologies, ontologies, epistemologies and methodologies' that guide different categories of action such as interventions or research. ${ }^{33}$ The meta-narrative review aims at making sense of 'complex and heterogeneous literature disagreeing about epistemology, ontology and research approaches', ${ }^{35}$ and focuses on the theoretical and conceptual basis of empirical studies. As such, it is a relevant approach for the broader study on accountability in local health systems, given the heterogeneous literature on accountability. Meta-triangulation reviews look for 'bridges' between concepts, theories and frameworks and explore tensions between different paradigms in order to build more comprehensive theories. 'It is a strategy of applying paradigmatic diversity to foster greater insight and creativity'. ${ }^{33}$ Both approaches use similar synthesis techniques, that is, narrative synthesis of findings on the basis of exploration of commonalities, differences and tensions in assumptions underlying the different research traditions, followed by higher level abstraction. $^{32}$

As mentioned above, we selected political science, public administration, organisational sociology, ethics and development studies as the disciplines to be covered, because these are the disciplines at the origins of theory-building and conceptual development on accountability. The lead author is a political scientist and 
anthropologist, with a $\mathrm{PhD}$ in public health, and has research and professional experience in the domains of development studies, political science, policy and public health in low and middle income countries (LMIC) in Africa. She is currently working at an institute of development studies and a tropical medicine research institute. Similarly, the coauthor has rich experience in research and policy development, including accountability, in LMIC and in global health institutions, and is working at an institute of tropical medicine.

The review questions were formulated as follows (see table 1):

- What are the main approaches to accountability in the selected research traditions?

- How is accountability defined?

- Who is to be accountable to whom, for what and why?

The search covered peer-reviewed journals, monographs and article readers published in the period 19922012. To identify monographs and article readers, we searched the academic database ISI Web of Knowledge, did manual searching for online full-text collections of Wiley InterScience, SpringerLink, Sage and Elsevier and used snowballing (referencing of references). As theorybuilding and conceptual development were the key review interests, monographs and readers constituted a primary reference source. In addition, we reviewed journal top 10 rankings in each discipline (table 1). For each of the aforementioned disciplines, we selected the journals on the basis of expert advice or because we found relevant articles published by these journals as a reference in other articles pertaining to accountability in LMIC. In addition, much-cited journals of renown without Journal Impact Factor scores were selected.

\begin{tabular}{llll} 
Table 1 Overview of journals selected & & \\
\hline Discipline & Journal & JIF & Results \\
\hline Political & Governance & 1.604 & 17 \\
science/public & Public Administration & 1.546 & 28 \\
administration & Review & & \\
Development & World Development & 1.527 & 9 \\
studies & $\begin{array}{l}\text { Public Administration } \\
\text { and Development }\end{array}$ & 1.21 & 28 \\
Organisational & Academy of & 7.475 & 1 \\
sociology/ & Management Review & & \\
management & $\begin{array}{l}\text { Organisation Science } \\
\text { Voluntas-International }\end{array}$ & 4.338 & 1 \\
& $\begin{array}{l}\text { Journal of Voluntary } \\
\text { and Non-Profit }\end{array}$ & & 14 \\
& Organisations & & \\
& $\begin{array}{l}\text { Non-Profit and } \\
\text { Voluntary Sector }\end{array}$ & 1.490 & 18 \\
& Quarterly & & \\
& Ethics & - & 86 \\
Ethics & Public Health Ethics & 0.788 & 1 \\
& Quarterly of & 0.846 & 3 \\
& Healthcare Ethics & & \\
\hline
\end{tabular}

Papers that contribute to theoretical development of the accountability concept in one of the aforementioned disciplines were included. When finding both, the theoretical model ${ }^{28} 36$ was chosen as the source instead of its empirical application. ${ }^{37-42}$ Critiques that do not offer an alternative or theoretically different model were excluded $^{43-46}$. Papers presenting empirical studies without conceptual framework, and papers focusing exclusively on global governance or global policymaking, on financial accountability or which were only applicable to high-income countries, were also excluded (figure 1).

The Google Scholar or Google (monographs) citation frequency is mentioned in table 1 and was used as an additional criterion of appraisal of the article's importance in the research tradition, ${ }^{\mathrm{i}}$ next to other authors' citation of the article and its alignment with the research question. It should be noted that citation frequency is just one criterion used in a meta-narrative review. Indeed, the aim is not to search just for the most popular publications, but also for the breadth of approaches within each discipline.

Thirty-four publications were retained for in-depth analysis (box 1).

We analysed the constituent elements of the frameworks and theories presented in these papers as follows in table 2:

- The authors' definition of accountability

- The accountability relationship (who is accountable to whom?)

- The accountability dimension (what is one accountable for?)

- The basis for the accountability claim (why is one accountable?)

- The causal model: what are the processes and instruments, the contextual conditions and (expected) outcomes?

We would like to indicate some limitations in the application of the methods. Monographs and readers constituted a primary reference source. Since there is no specific book database covering monographies and readers in the disciplines included here, the review could not be entirely comprehensive. Another limitation is that we may have inadvertently ignored specific journals and some key authors, some of whom inevitably published after the timeframe included in the review.

\section{RESULTS}

We present here the main themes we identified within the literature of each reviewed discipline, based on the overview in table 2. The first section presents an overview of disciplinary approaches, the second section traces the concept of accountability, and the third section provides a final summary presenting four main paradigms.

${ }^{\mathrm{i}}$ Google Scholar citation tracing was conducted in October 2013. 


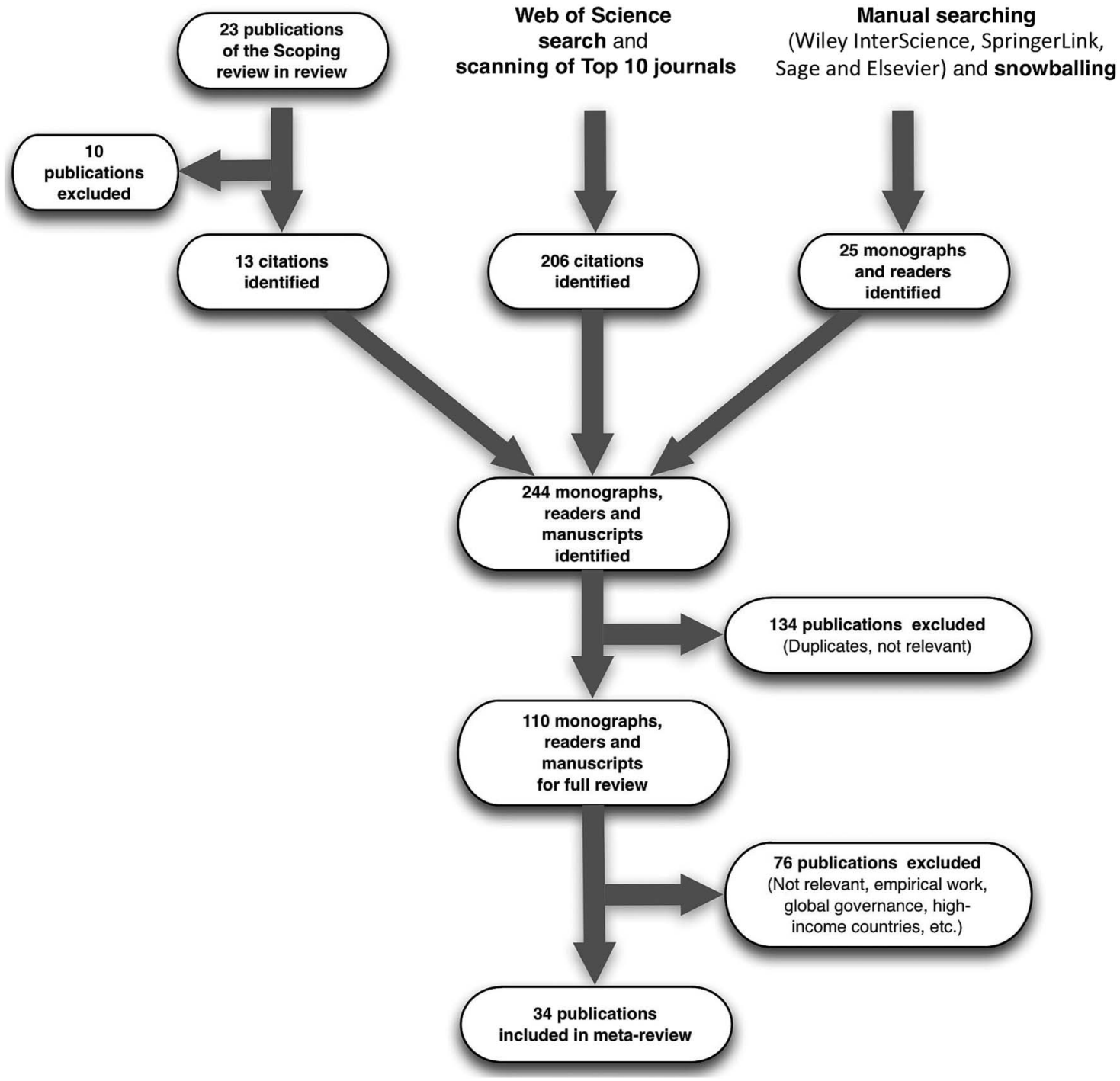

Figure 1 Search results for the meta-narrative review.

\section{Disciplinary approaches}

In the discipline of political science/public administration, the publications reviewed focused mainly on the accountability relationship between different categories of actors involved in public policy, often referring to the multitude of actors involved in public policy (as accountors), and to the notion of 'citizens' or 'stakeholders'. For these authors, public policy actors are accountable to citizens for performance and compliance with regulations, as they possess delegated power or authority on behalf of the citizens. Financial accountability is separately mentioned by most authors. Processes to improve accountability focus on the supply side and include: reporting, public investigation and the verification of standards.

The publications reviewed in the discipline of development studies show various influences. Newell and Bellour ${ }^{47}$ and Newell and Wheeler ${ }^{48}$ consider accountability as grounded in citizens' rights, which can be enforced through empowerment of citizens and their collective action. As such, social justice can be achieved. On the other hand, for Paul, the accountability claim is grounded in a power relationship: the customer can 'voice' his concerns over bad performance and can 'exit' the service, that is, no longer make use of the services in question. ${ }^{49}$ In Ackerman's view, accountability in service delivery can only be improved via 'co-governance'actual participation of citizens in decision-making. ${ }^{50}$

The works reviewed in the field of organisational sociology are concerned with accountability within and of organisations. Accountability is mainly considered as a function of organisations, which, if managed well, contributes to gaining the public's trust. Kearns ${ }^{51}$ adheres to the view of accountability as a function directed towards the organisation's external environment. In this view, proactively maintaining accountability relationships is an integral part of the organisation's strategic management and leadership function. In contrast, Frink and $\mathrm{Klimosk}^{52}$ view accountability of an organisation as an internal function, which they relate to organisational culture. 
Box 1 List of papers that were selected in the review

1. Ackerman S. Co-Governance for accountability: beyond "Exit" and "Voice". World Dev 2004;32:447-63.

2. Behn RD. Rethinking democratic accountability. Washington DC: Brookings Institution Press, 2001.

3. Boin A, McConnell A, Hart PT. Governing after crisis. The politics of investigation, accountability and learning. Cambridge: Cambridge University Press, 2008.

4. Bovens M. The Quest for Responsibility. Accountability and citizenship in complex organisations. Cambridge: Cambridge University Press, 1998.

5. Bovens M, Schillemans T, Hart PT. Does public accountability work? An assessment tool. Public Adm 2008;86:225-42.

6. Brown LD, Moore MH. Accountability, strategy and international nongovernmental organizations. Nonprofit Voluntary Sector $Q$ 2001;30:569-87.

7. Cornwall A, Coelho VSP. Spaces for change? The politics of participation in new democratic arenas. In: Cornwall A, Coelho VSP, eds. Spaces for change? The politics of participation in new democratic arenas. London: Zed Books, 2007:1-32.

8. Daniels N. Accountability for reasonableness. BMJ 2000;321:1300-1.

9. Daniels N. Just health. Meeting health needs fairly. Cambridge: Cambridge University Press, 2008.

10. Daniels N, Sabin JE. Setting limits fairly: can we learn to share medical resources? New York/Oxford: Oxford University Press, 2002.

11. Devas N, Grant U. Local government decision-making-citizen participation and local accountability: some evidence from Kenya and Uganda. Public Adm Dev 2003;23:307-16.

12. Dubnick M. Accountability and the promise of performance. Public Performance Manage Rev 2005;28:376-417.

13. Ebrahim A. Accountability in practice: mechanisms for NGOs. World Dev 2003;31:813-29.

14. Ebrahim A. Making sense of accountability: conceptual perspectives for northern and southern nonprofits. Nonprofit Manag Leadersh 2003;14:191-211.

15. Ebrahim A. Accountability myopia: Iosing sight of organisational learning. Nonprofit Voluntary Sector Q 2005;34:56-87.

16. Edwards M, Hulme M. NGO performance and accountability: introduction and overview. In: Edwards M, Hulme M, eds. Non-Governmental organisations — performance and accountability beyond the magic bullet. London: Earthscan, 1995:3-16.

17. Frink D, Klimoski RJ. Advancing accountability theory and practice. Introduction to the human resource management review special edition. Hum Resour Manag Rev 2004;14:1-17.

18. Gregory R. Accountability in modern government. In: Peters BG, Pierre J, eds. Handbook of public administration. London: Sage, 2003:557-68.

19. Kearns KP. Managing for accountability. Preserving the public trust in public and non-profit organizations. San Francisco: Jossey-Bass, 2010.

20. Kilby P. Accountability for empowerment: dilemmas facing non-governmental organizations. World Dev 2006;34:951-963.

21. Koppell J. Pathologies of accountability: ICANN and the challenge of "Multiple Accountabilities Disorder". Public Adm Rev 2005;65:94108.

22. Koppell J. The politics of quasi-government. Hybrid organizations and the dynamics of bureaucratic control. Cambridge: Cambridge University Press, 2006.

23. Moncrieffe J. Relational accountability. Complexities of Structural Injustice. London: Zed Books, 2011.

24. Mulgan R. Accountability. An ever-expanding concept? Public Adm 2000;78:555-73.

25. Mulgan R. Holding power to account: accountability in modern democracies. London: Palgrave MacMillan, 2003.

26. Najam A. NGO accounability: a conceptual framework. Dev Policy Rev 1996;14:339-53.

27. Newell P, Bellour S. Mapping accountability: origins, contexts and implications for development. IDS Working Paper 168. Brighton: Institute for Development Studies, 2002:24.

28. Newell P, Wheeler J. Rights, resources and the politics of accountability: an introduction. In: Newell P, Wheeler J, eds. Rights, resources and the politics of accountability. London: Zed Books, 2006:1-36.

29. Ospina S, Diaz W, O'Sullivan JF. Negotiating accountability: managerial lessons from identity-based nonprofit organizations. Nonprofit Voluntary Sector Q 2002;31:5-31.

30. Paul S. Accountability in public services: exit, voice and control. World Dev 1992;20:1047-60.

31. Romzek BS, LeRoux K, Blackmar JM. A preliminary theory of informal accountability among network organizational actors. Public Adm Rev 2012;72:442-53.

32. Schedler A. Conceptualizing accountability. In: Schedler A, Diamond L, Plattner MF, eds. The self-restraining state power and accountability in new democracies. Boulder, C0: Lynne Rienner, 1999:13-28.

33. Schedler A, Diamond L, Plattner MF, eds. The self-restraining state. Power and accountability in New Democracies. Boulder, CO: Lynne Rienner, 1999.

34. Steets J. Accountability in public policy partnerships. Basingstoke: Palgrave Macmillan, 2010.

Social justice and equity grounded in fair decisionmaking is the outcome envisaged in the discipline of ethics. For Daniels ${ }^{28}$ and Moncrieffe, ${ }^{53}$ accountability is part and parcel of a democratic culture that counters unbridled power. The Rawls-inspired 'Accountability for Reasonableness' framework developed by Daniels 283654 focuses on the fairness of the accountability process. For Daniels, ${ }^{28}$ supply-side measures such as enforcing compliance to rules, transparency and involvement of stakeholders can only work when these are supported by a strong demand from an empowered civil society. 
Table 2 Summary of the results of the meta-review

\begin{tabular}{|c|c|c|c|c|c|c|c|c|}
\hline Discipline & Authors & $\begin{array}{l}\text { Accountability } \\
\text { definition }\end{array}$ & $\begin{array}{l}\text { Who is accountable } \\
\text { to whom? }\end{array}$ & For what? & Why? & Processes & Outcomes & $\begin{array}{l}\text { Contextual } \\
\text { conditions }\end{array}$ \\
\hline \multirow[t]{5}{*}{$\begin{array}{l}\text { Political } \\
\text { science/public } \\
\text { administration }\end{array}$} & Steets, ${ }^{95}$ & $\begin{array}{l}\text { Partnership } \\
\text { accountability } \\
\text { (partnership: voluntary } \\
\text { arrangement between } \\
\text { public, and/or private } \\
\text { and/or civil society } \\
\text { actors) }\end{array}$ & $\begin{array}{l}\text { Multitude of } \\
\text { organisations } \\
\text { involved in public } \\
\text { policy to formal and } \\
\text { informal principals } \\
\text { and legal and fiscal } \\
\text { authorities }\end{array}$ & $\begin{array}{l}\text { Finances } \\
\text { compliance with } \\
\text { rules and } \\
\text { processes } \\
\text { performance }\end{array}$ & $\begin{array}{l}\text { Delegated } \\
\text { authority }\end{array}$ & $\begin{array}{l}\text { Information } \\
\text { enforcement- } \\
\text { clarifying roles } \\
\text { and expectations } \\
\text { of principals and } \\
\text { agents }\end{array}$ & Not mentioned & $\begin{array}{l}\text { Collaboration } \\
\text { between } \\
\text { actors }\end{array}$ \\
\hline & $\begin{array}{l}\text { Mulgan, }{ }^{96} \\
\text { Mulgan, }^{30}\end{array}$ & $\begin{array}{l}\text { Plural accountability in } \\
\text { modern democracies }\end{array}$ & $\begin{array}{l}\text { Government and } \\
\text { public institutions to } \\
\text { citizens or } \\
\text { organisations that act } \\
\text { on citizen's behalf } \\
\text { (networks of } \\
\text { accountability) }\end{array}$ & $\begin{array}{l}\text { Performance } \\
\text { compliance with } \\
\text { rules and } \\
\text { regulations }\end{array}$ & $\begin{array}{l}\text { Delegated } \\
\text { power, } \\
\text { retributive justice } \\
\text { and public } \\
\text { deliberation }\end{array}$ & $\begin{array}{l}\text { Reporting, } \\
\text { justification } \\
\text { effective } \\
\text { rectification: } \\
\text { sanctions, } \\
\text { remedial action }\end{array}$ & Responsiveness & Responsibility \\
\hline & Behn, ${ }^{60}$ & $\begin{array}{l}\text { Mutual compact } \\
\text { accountability }\end{array}$ & $\begin{array}{l}\text { Public managers to } \\
\text { multiple stakeholders/ } \\
\text { citizens }\end{array}$ & $\begin{array}{l}\text { Finances, } \\
\text { fairness through } \\
\text { rules and } \\
\text { processes } \\
\text { performance }\end{array}$ & $\begin{array}{l}\text { Flexibility in } \\
\text { management }\end{array}$ & $\begin{array}{l}\text { Verification of } \\
\text { standards for } \\
\text { processes and } \\
\text { trust regarding } \\
\text { performance }\end{array}$ & Not mentioned & $\begin{array}{l}\text { Cooperation, } \\
\text { collective } \\
\text { action }\end{array}$ \\
\hline & Boin et $a \beta^{37}$ & Political accountability & $\begin{array}{l}\text { Political actors and } \\
\text { institutions to } \\
\text { stakeholders }\end{array}$ & $\begin{array}{l}\text { Goal } \\
\text { achievements }\end{array}$ & $\begin{array}{l}\text { Name and } \\
\text { shame }\end{array}$ & $\begin{array}{l}\text { Public } \\
\text { investigation }\end{array}$ & $\begin{array}{l}\text { Improved } \\
\text { performance } \\
\text { public } \\
\text { institutions }\end{array}$ & $\begin{array}{l}\text { Vibrant media, } \\
\text { civil society }\end{array}$ \\
\hline & Schedler ${ }^{58}$ & $\begin{array}{l}\text { Public sector } \\
\text { accountability }\end{array}$ & $\begin{array}{l}\text { Public institutions to } \\
\text { citizens }\end{array}$ & $\begin{array}{l}\text { Political, } \\
\text { financial, } \\
\text { administrative, } \\
\text { legal, } \\
\text { professional }\end{array}$ & Not mentioned & $\begin{array}{l}\text { Answerability and/ } \\
\text { or enforcement }\end{array}$ & $\begin{array}{l}\text { To curb or } \\
\text { control political } \\
\text { power }\end{array}$ & Not mentioned \\
\hline \multirow[t]{2}{*}{$\begin{array}{l}\text { Development } \\
\text { studies }\end{array}$} & $\begin{array}{l}\text { Newell and } \\
\text { Bellour, } 47 \\
\text { Newell and } \\
\text { Wheeler }^{48}\end{array}$ & $\begin{array}{l}\text { Rights-based } \\
\text { accountability }\end{array}$ & Institutions to citizens & Resources & $\begin{array}{l}\text { Empowerment } \\
\text { through } \\
\text { collective action }\end{array}$ & $\begin{array}{l}\text { Strengthening } \\
\text { demand side } \\
\text { accountability: } \\
\text { 'enforcing rights } \\
\text { over resources' }\end{array}$ & Social justice & Not mentioned \\
\hline & $\begin{array}{l}\text { Devas and } \\
\text { Grant }^{59}\end{array}$ & $\begin{array}{l}\text { Political accountability } \\
\text { at multiple levels } \\
\text { (central-decentralised } \\
\text { levels) }\end{array}$ & $\begin{array}{l}\text { Multiple accountability } \\
\text { relationships between } \\
\text { government, } \\
\text { decentralised } \\
\text { government agencies, } \\
\text { public administration } \\
\text { and citizens }\end{array}$ & Resources & Not mentioned & $\begin{array}{l}\text { Information central } \\
\text { level leadership }\end{array}$ & Public trust & $\begin{array}{l}\text { Political will } \\
\text { government }\end{array}$ \\
\hline
\end{tabular}




\begin{tabular}{|c|c|c|c|c|c|c|c|c|}
\hline Discipline & Authors & $\begin{array}{l}\text { Accountability } \\
\text { definition }\end{array}$ & $\begin{array}{l}\text { Who is accountable } \\
\text { to whom? }\end{array}$ & For what? & Why? & Processes & Outcomes & $\begin{array}{l}\text { Contextual } \\
\text { conditions }\end{array}$ \\
\hline & Paul $^{49}$ & $\begin{array}{l}\text { Microlevel exit and } \\
\text { voice accountability }\end{array}$ & $\begin{array}{l}\text { Public sector } \\
\text { institutions towards } \\
\text { citizens }\end{array}$ & Service delivery & Customer power & $\begin{array}{l}\text { Strengthening } \\
\text { demand } \\
\text { mechanisms exit } \\
\text { and voice based } \\
\text { on information, } \\
\text { organisational } \\
\text { incentives }\end{array}$ & $\begin{array}{l}\text { Service } \\
\text { performance } \\
\text { improvement }\end{array}$ & $\begin{array}{l}\text { Perceived } \\
\text { advantages } \\
\text { and costs of } \\
\text { using exit and } \\
\text { voice }\end{array}$ \\
\hline & Ackerman $^{50}$ & Social accountability & Not mentioned & Service delivery & $\begin{array}{l}\text { Co-governance } \\
\text { or empowered } \\
\text { participatory } \\
\text { governance }\end{array}$ & $\begin{array}{l}\text { Participation in } \\
\text { decision-making }\end{array}$ & Not mentioned & Not mentioned \\
\hline \multirow[t]{2}{*}{$\begin{array}{l}\text { Organisational } \\
\text { sociology }\end{array}$} & $\begin{array}{l}\text { Frink and } \\
\text { Klimoski }^{52}\end{array}$ & $\begin{array}{l}\text { Organisational and } \\
\text { self-accountability } \\
\text { (internal) }\end{array}$ & $\begin{array}{l}\text { Employee to } \\
\text { organisation }\end{array}$ & Not mentioned & Authority & $\begin{array}{l}\text { Social norms and } \\
\text { norm } \\
\text { expectations, } \\
\text { evaluation, } \\
\text { sanctions }\end{array}$ & $\begin{array}{l}\text { Long-term } \\
\text { organisational } \\
\text { viability }\end{array}$ & Not mentioned \\
\hline & Kearns $^{51}$ & $\begin{array}{l}\text { Organisational } \\
\text { accountability (external) }\end{array}$ & $\begin{array}{l}\text { Organisation to the } \\
\text { public }\end{array}$ & $\begin{array}{l}\text { Compliance } \\
\text { with rules, laws } \\
\text { and regulations } \\
\text { +answering the } \\
\text { public's } \\
\text { expectations }\end{array}$ & $\begin{array}{l}\text { Organisation } \\
\text { needs to be } \\
\text { deserving of the } \\
\text { public's trust }\end{array}$ & $\begin{array}{l}\text { Monitoring } \\
\text { organisational } \\
\text { standards of } \\
\text { accountability }\end{array}$ & Public trust & Not mentioned \\
\hline \multirow[t]{2}{*}{ Ethics } & Daniels $^{28}$ & $\begin{array}{l}\text { 'Accountability for } \\
\text { reasonableness' }\end{array}$ & Institutions to citizens & $\begin{array}{l}\text { Resource } \\
\text { allocation of } \\
\text { primary social } \\
\text { goods that } \\
\text { support human } \\
\text { capabilities }\end{array}$ & $\begin{array}{l}\text { Collective action } \\
\text { curbs power }\end{array}$ & $\begin{array}{l}\text { Fair } \\
\text { decision-making } \\
\text { processes }\end{array}$ & Social justice & $\begin{array}{l}\text { Common } \\
\text { value of } \\
\text { fairness in } \\
\text { process }\end{array}$ \\
\hline & Moncrieffe $^{53}$ & Relational accountability & $\begin{array}{l}\text { Democratic } \\
\text { institutions to citizens }\end{array}$ & $\begin{array}{l}\text { Dependent on } \\
\text { the actor and } \\
\text { the context }\end{array}$ & Power & $\begin{array}{l}\text { Equity based } \\
\text { democratic } \\
\text { institutions and } \\
\text { decision-making }\end{array}$ & $\begin{array}{l}\text { Human } \\
\text { development, } \\
\text { democratic } \\
\text { stability }\end{array}$ & $\begin{array}{l}\text { Democratic } \\
\text { culture, } \\
\text { institutional } \\
\text { context }\end{array}$ \\
\hline
\end{tabular}


Tracing the evolution of the concept of 'accountability'

The emergence of New Public Management in the 1980 s and its uptake in health policy and systems led to an active interest in governance and improved state accountability. ${ }^{30}{ }^{55}$ During this period, development and donor agencies like the World Bank argued that states were failing their citizens and that governance systems were weak and non-responsive towards their citizens. It was argued that traditional public administration, grounded in hierarchy and rules, no longer provided fitting answers to rapidly changing environments. In response, the World Bank focused much on statebuilding interventions and 'good governance'. In practice, health policies were reoriented towards decentralisation, provider-purchaser split, deregulation and contracting. The latter was considered as a central strategy to increase accountability of state actors, combined with deregulation and development of the private sector.

The World Bank followed the ideas of Paul, ${ }^{49}$ who proposed to strengthen both 'exit' (only a viable option for patients if alternative services exist) and 'voice' mechanisms to bolster accountability of public sector agencies. Paul, following Hirschman, ${ }^{56}$ argued that supply side competition enabling exit and participatory mechanisms enabling voice are effective only when they are bolstered by organisational incentives and adequate information and monitoring systems exist. Later, Roberts ${ }^{57}$ criticised adherents of New Public Management for reducing accountability to an issue, which can be solved by administrative regulation.

The much-cited monograph 'The Self-Refraining State' by Schedler et a $\tilde{l}^{58}$ offers insights on how public administration looked at accountability from a different perspective. It provides an early comprehensive conceptualisation of accountability that was intended to shape public sector reform policy in Africa and Latin America. Schedler et al consider accountability deficiencies as a failure of institutional arrangements to constrain power imbalances. The authors developed a two-dimensional concept of accountability, grounded in answerability and enforceability. Answerability is the obligation of civil servants to explain their actions, and enforceability is the capacity to sanction any wrongdoing of public officials or violation of the public service orientation. ${ }^{58}$

In the late 1990s, public administration scholars acknowledged the increased plurality of society and the effects of globalisation. They argued that in an interdependent world with multiple centres of decisionmaking, the relationships between state, civil society and the market become increasingly complex and opaque. Authors like Mulgan, ${ }^{30}$ Devas and Grant ${ }^{59}$ and Behn ${ }^{60}$ see contemporary accountability relationships as plural and dispersed among many actors and policymaking levels. However, multiple relations lead to multiple types of accountability, which in turn give rise to competing demands. Also, international organisations ${ }^{30}$ and partnerships between the public sector, private sector and civil society ${ }^{31}$ were considered to be surrounded by networks of accountability relations.

Three consequences of this hyperconnectedness were identified. First, organisations were seen to suffer from 'multiple accountability disorder, ${ }^{, 61}$ unable to respond to potentially conflicting demands for accountability. ${ }^{60}$ Second, Ackerman ${ }^{50}$ urged moving beyond mere 'exit' and 'voice' mechanisms and to provide new space for participatory mechanisms. Informal accountability in the form of enabling public dialogue was seen as a potential reinforcement of more traditional hierarchical accountability mechanisms. ${ }^{62}$ Third, attention was given to the mechanisms underlying accountability. While Schedler et al had identified answerability and enforceability as conditions for accountability, Dubnick ${ }^{63}$ pointed to three main processes that constitute account-giving behaviour: 'reporting', 'mitigating' and 'reframing'. He identified the desire for approval or the urge to conform as mechanisms underlying accountability.

\section{Four main paradigms to accountability}

Table 2 shows how the authors we reviewed present a diversity of views and ideas on accountability. Yet, four distinct paradigms of accountability emerge: the institutionalist, the rights-based, the individual choice and the collective action paradigm.

The institutionalist paradigm proposes to use formal procedures and instruments and social norms in organisations and institutions to improve accountability. Accountability is mostly based on hierarchical relationships that are embedded in a 'command and control' bureaucratic structure and culture. ${ }^{64}$ It is enforced through verifying compliance with procedures, rules, laws and policies. Most of the frameworks within this approach have improved performance as the intended outcome. Institutionalist strategies sometimes entail community or stakeholder participatory processes as part of the stakeholder engagement or the monitoring and evaluation function of an organisation. ${ }^{181051526165-70}$

The rights-based paradigm starts from the premise that accountability relationships rest on individual human rights or entitlements. Citizens delegate power and authority to government and public sector institutions, which in turn are accountable for the progressive realisation of citizens' rights and entitlements. Accountability is considered to be a value on itself: it is the key to curbing power differentials and bringing about more equitable relations through resource redistribution. Legal procedures can be a basis for enforcing accountability. Authors representing this line of thinking include. ${ }^{182128} 313659607172$

The individual choice paradigm regards accountability from a client perspective and relies on competitive market behaviour to explain accountability relationships. It considers that clients, as individual actors, make rational choices by weighing the perceived advantage and cost of all options. If the public sector institution is not delivering the appropriate service to the client, the 
latter can exercise his/her power as client and exit the service. Strategies to strengthen client power are based on verification of performance measures. ${ }^{49} 63$ 73-75

In the collective action paradigm, accountability is seen as the product of groups of citizens. Individuals, organisations and institutions are considered to be connected by multiple accountability relationships. Actors can thus be account holder for some actions and accountor for other at the same time. The meaning of accountability is considered to be socially constructed and dependent on a given context. Actors can demand accountability through investigation and audits, 'naming and shaming' (through channels such as the media) and civil society protest. Alternatively, accountability is negotiated in a dialogue between the organisation and the public. ${ }^{1722} 48505376-81$

Each of these paradigms differs in how accountability is defined and how it can be ensured. In the rights-based paradigm, improved accountability is an end in itself, while in the institutionalist paradigm it is a means to an end, that is, improved performance. The institutionalist paradigm primarily proposes measures on the 'supply' side to improve accountability, while the individual choice and collective action paradigms consider that accountability needs to be enforced by the account holders.

On the basis of the review of the literature and our professional background, we argue that the paradigms complement each other as in health services, accountability can be improved by taking measures both on the 'supply' and the 'demand' side.

\section{DISCUSSION: RELEVANCE OF ACCOUNTABILITY APPROACHES AND CONCEPTS FOR HEALTH SYSTEMS}

The importance of accountability is now generally acknowledged in the fields of health policy and systems and global health, but it remains an elusive concept. Our meta-narrative review of current theories and frameworks in political science, public administration, organisational sociology, ethics and development studies indeed confirms that there is a wide range of approaches and definitions of accountability. This contributes potentially to the perception that there is no coherent body of knowledge. This in turn explains in part the research difficulties concerning accountability. ${ }^{22} 73$ Certain authors were not picked up by our search, such as John Gaventa and Anne Marie Goetz. ${ }^{82-85}$

Our analysis shows that four paradigms of accountability can be identified: the institutionalist, the rights-based, the individual choice and the collective action paradigm. Each of these emerged in reaction to specific challenges, which is reflected in the focus on specific relations and actors from either a professional, political, social or organisational perspective. This reflects Lasker's view that accountability approaches appear to suffer from the same predicament as work on community participation: 'Practitioners and researchers (...) come from a variety of contexts, initiatives, and academic disciplines and few of them have integrated their work with experiences or literatures beyond their own domain'. ${ }^{86}$ While the disciplines here reviewed do not exist in silos, some accountability strategies remain limited to particular relations and actions and to ignoring the complex relationships between the multiple state and non-state actors in the current mixed health systems' landscape in LMIC.

We argue that the four paradigms should be considered as complementary, that accountability may require action on both the 'demand-side' and 'supply-side', and that accountability can be both considered as a means to improve performance of health systems and as an end in itself. We thus propose to integrate the four main approaches to accountability in one comprehensive operational framework (figure 2).

This model has four dimensions: a provider, organisational, social and political dimension (box 2). The dimensions are not mutually exclusive and closed. Rather, the provider dimension is embedded in the organisational dimensions, which in itself is part of the social and political dimension.

The provider dimension focuses on the providerpatient relationship, in which one would use accountability measures and processes as an instrument to enhance quality of care. Examples include clinical audits. The organisational dimension focuses on responsiveness of the organisation to its stakeholders. Symptom boxes, ombudsman services and client satisfaction surveys can be used here. In the political dimension, one focuses primarily on regulatory processes in institutions to protect the public interest and to enhance the outcome of citizen trust. Finally, in the social dimension, strengthened public accountability is perceived mainly

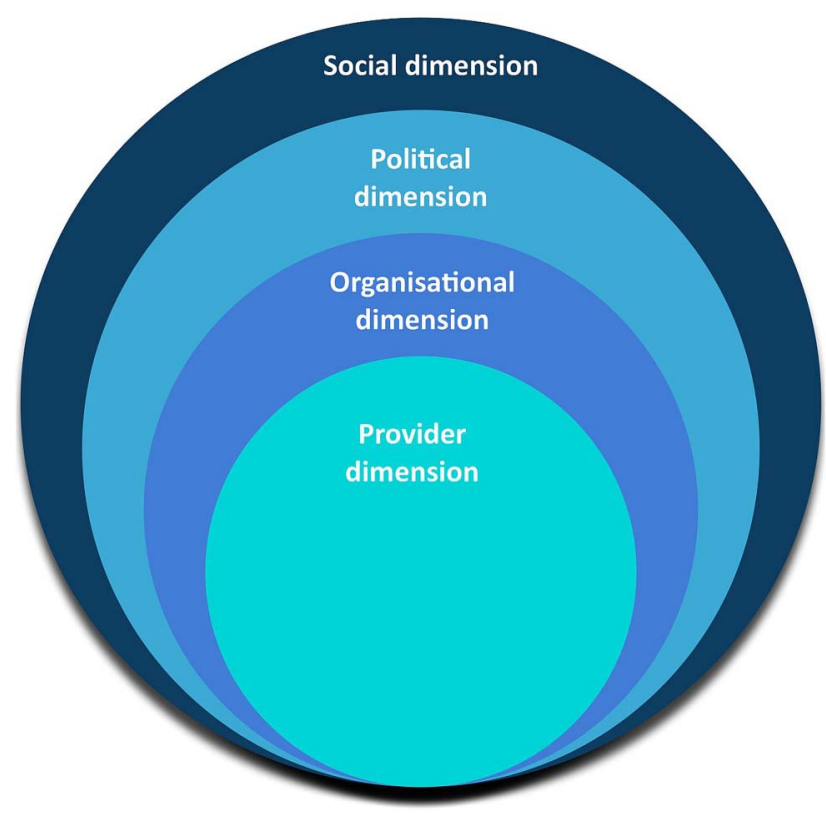

Figure 2 Multidimensional frame of public accountability in health systems. 
Box 2 Four dimensions of accountability in health systems

The provider dimension is based on professional ethos and providers' commitment to quality of care and responsiveness. Strategies to enhance provider accountability include socialisation into the profession, enforcing professional standards and ethical codes, peer reviews and other remedial actions.

Organisational accountability is primarily undertaken to improve the organisational performance or to ensure that the organisation is responsive to its stakeholders. Measures to enhance accountability entail policies to enhance transparency and community control (including means for external verification), as well as the use of staff incentives to engage in dialogue with service users, performance reviews and organisational audits.

Accountability in the political dimension entails measures to safeguard the public interest and to improve citizens' trust towards institutions to which they mandated certain responsibilities and means. Measures involve regulation processes based on mutually agreed roles and responsibilities between the actors in the health system and commonly agreed means for public participation in decision-making, including public investigation and public redress mechanisms.

Accountability measures specific to the social dimension of accountability involve relations and social processes. This includes processes of information sharing within self-organised networks (participatory processes in an organisational prioritysetting), and collective action to redress unfairness and rights violations. The outcome of enhancing accountability in the social dimension is the bolstering of equity and fairness in the system.

as an instrument to enhance equity and social justice grounded in community self-organisation.

This multidimensional frame has a number of advantages. First, it reflects the current multirelational nature of health systems and can help in identifying which accountabilities play out in which dimension. For instance, at the local level of health systems, district health managers might need to ensure accountability in the professional, the organisational and the political dimension, all at the same time. In effect, they might be accountable to standards set by a professional association, be accountable as employees of a particular healthcare organisation and be accountable as representatives of a public health institution. Second, the framework allows for identifying the roles of account-holder and accountor that actors and organisations often play simultaneously. For instance, the same district health managers are to hold their staff accountable for delivering quality services, while being themselves accountable to the public for the use of public funds. Third, it could inform the development of a tool to assess gaps in accountability. Finally, the frame points to the need for developing comprehensive accountability strategies that span the dimensions in which the organisation needs to be accountable. Indeed, if accountability has four dimensions, accountability interventions have to consist of bundled strategies that act on the different dimensions to be effective, taking into account the multiple relations of actors in the local health system.

Of course, numerous questions remain as to the applicability of this frame and how it could be translated into practical tools to assess the degree of public accountability.

\section{CONCLUSIONS}

Our meta-narrative review found that the literature on accountability in political science, public administration, organisational sociology, ethics and development studies displays a wide variation of definitions and concepts. Four main groups of approaches emerge: the institutionalist approach, the rights-based approach, the individual choice approach and the collective action approach. These four approaches can be integrated in a comprehensive accountability framework with professional, organisational, social and political dimensions.

Contributors SVB conceived the review, carried out the search and the analysis and wrote the manuscript. SHM contributed to the review design, commented on the analysis and contributed to the writing of the final manuscript. Both authors read and approved the final manuscript.

Funding This research received no specific grant from any funding agency in the public, commercial or not-for-profit sectors.

Competing interests None declared.

Provenance and peer review Not commissioned; externally peer reviewed.

Data sharing statement No additional data are available.

Open Access This is an Open Access article distributed in accordance with the Creative Commons Attribution Non Commercial (CC BY-NC 4.0) license, which permits others to distribute, remix, adapt, build upon this work noncommercially, and license their derivative works on different terms, provided the original work is properly cited and the use is non-commercial. See: http:// creativecommons.org/licenses/by-nc/4.0/

\section{REFERENCES}

1. Emanuel EJ, Emanuel LL. What is accountability in healthcare? Ann Intern Med 1996;124:229-39.

2. Loewenson R. Participation and accountability in health systems: the missing factor in equity? Harare, Zimbabwe: Training and Research Support Centre, 2002.

3. Rifkin SB. Lessons from community participation in health programmes. Health Policy Plan 1986;1:240-9.

4. Rifkin SB. Community Participation in MCH/FP programmes: an analysis based on case study materials. Geneva: WHO, 1990.

5. Rifkin SB. Ten best readings on community participation and health. Afr Health Sci 2001;1:42-5.

6. Pérez D, Lefévre P, Romero MI, et al. Augmenting frameworks for appraising the practices of community based health interventions. Health Policy Plan 2009;24:335-41.

7. Hafner T, Shiffman J. The emergence of global attention to health system strengthening. Health Policy Plan 2013;28:41-50.

8. Mikkelsen-Lopez I, Wyss K, de Savigny D. An approach to addressing governance from a health system framework perspective. BMC Int Health Hum Rights 2011;11:13.

9. WHO. Everybody's business: strengthening health systems to improve health outcomes: WHO's framework for action. Geneva: World Health Organization, 2007.

10. Siddiqi S, Masud TI, Nishtar S, et al. Framework for assessing governance of the health systems in developing countries: gateway to good governance. Health Policy 2009;90:13-25.

11. Atun $R$, de Jongh $T$, Secci $F$, et al. Integration of targeted health interventions into health systems: a conceptual framework for analysis. Health Policy Plan 2010;25:104-11.

12. Gruskin S, Ahmed S, Bogecho D, et al. Human rights in health systems frameworks: what is there, what is missing and why does it matter? Glob Public Health 2012;7:337-51. 
13. Balabanova D, McKee M, Mills A, et al. What can global health institutions do to help strengthen health systems in low income countries? Health Res Policy Syst 2010;8:22.

14. de Savigny D, Adam T. Systems thinking for health systems strengthening. Geneva: Alliance for Health Policy and Systems Research \& World Health Organisation, 2009.

15. Fattore G, Tediosi F. The importance of values in shaping how health systems governance and management can support universal health coverage. Value Health 2013;16(1, Supplement): S19-23.

16. Kruk ME, Freedman LP. Assessing health system performance in developing countries: a review of the literature. Health Policy 2008;85:263-76.

17. Béhague D, Kanhonou LG, Filippi V, et al. Pierre Bourdieu and transformative agency: a study of how patients in Benin negotiate blame and accountability in the context of severe obstetric events. Sociol Health IIIn 2008;30:489-510.

18. Freedman LP. Human rights, constructive accountability and maternal mortality in the Dominican Republic: a commentary. Int J Gynecol Obstet 2003;82:111-14.

19. George A. Using accountability to improve reproductive healthcare. Reprod Health Matters 2003;11:161-70.

20. George A. Accountability in health services. transforming relationships and contexts. Working Paper Series. Cambridge, MA: Harvard Center for Population and Development Studies, 2003.

21. Yamin AE. Beyond compassion: the central role of accountability in applying a Human Rights framework to health. Health Hum Rights 2008;10:1-20.

22. Molyneux S, Atela M, Angwenyi V, et al. Community accountability at peripheral health facilities: a review of the literature and development of a conceptual framework. Health Policy Plan 2012;27:541-54.

23. Bossert TJ, Mitchell AD. Health sector decentralization and local decision-making: decision space, institutional capacity and accountability in Pakistan. Soc Sci Med 2011;72:39-72.

24. Hsu J, Pitt C, Greco G, et al. Countdown to 2015: changes in official development assistance to maternal, newborn and child health in 2009-10, an assessment of progress since 2003. Lancet 2012;380:1157-68.

25. Kickbusch I. The development of international health policiesaccountability intact? Soc Sci Med 2000;51:979-89.

26. Ooms G, Hammond R. Global governance of health and the requirements of human rights. Global Policy 2012;3:476-9.

27. Requejo JH, Bryce J, Victora C, et al. Accountability for maternal, newborn and child survival. An update on progress in priority countries. Geneva: WHO/Countdown to 2015-Maternal, Newborn and Child Survival, 2012:18

28. Daniels N. Just health. Meeting health needs fairly. Cambridge: Cambridge University Press, 2008.

29. United Nations General Assembly. Resolution on Universal Health Coverage. 67th Session, 53rd Meeting, New York, 2012.

30. Mulgan R. Holding power to account: accountability in modern democracies. London: Palgrave MacMillan, 2003.

31. Steets J. Accountability in public policy partnerships. Basingstoke: Palgrave Macmillan, 2010.

32. Greenhalgh T, Robert G, Macfarlane F, et al. Storylines of research in diffusion of innovation: a meta-narrative approach to systematic review. Soc Sci Med 2005;61:417-30.

33. Lewis MW, Grimes AJ. Meta-triangulation: building theory from multiple paradigms. Acad Manage Rev 1999;24:672-90.

34. Wong G, Greenhalgh T, Westhorp G, et al. RAMESES publication standards: meta-narrative reviews. BMC Med 2013;11:20.

35. Greenhalgh T, Robert G, Macfarlane F, et al. Diffusion of innovations in service organization: systematic review and recommendations. Millbank Q 2004;82:581-629.

36. Daniels N, Sabin JE. Setting limits fairly: can we learn to share medical resources? New York/Oxford: Oxford University Press, 2002.

37. Byskov J, Bloch P, Blystad A, et al. Accountable priority setting for trust in health systems-the need for research into a new approach for strengthening sustainable health action in developing countries. Health Res Policy Syst 2009;7:23.

38. Mshana S, Shemilu H, Ndawi B, et al. What do district health planners in Tanzania think about improving priority setting using 'Accountability for Reasonableness'? BMC Health Serv Res 2007;7:180.

39. Maluka S, Kamuzora P, San Sebastiån M, et al. Decentralized health care priority-setting in Tanzania: evaluating against the accountability for reasonableness framework. Soc Sci Med 2010;71:751-9.
40. Maluka SO. Strengthening fairness, transparency and accountability in health care priority setting at district level in Tanzania. Glob Health Action 2011;4:7829.

41. Kapiriri L, Norheim OF, Heggenhougen K. Public participation in health planning and priority setting at the district level in Uganda. Health Policy Plan 2003;18:205-13.

42. Gibson JL, Martin DK, Singer PA. Priority setting in hospitals: fairness, inclusiveness, and the problem of institutional power differences. Soc Sci Med 2005;61:2355-62.

43. Rid A. Justice and procedure: how does "accountability for reasonableness" result in fair limit-setting decisions? J Med Ethics 2009;35:12-16.

44. Friedman A. Beyond accountability for reasonableness. Bioethics 2008;22:101-12.

45. Hasman A, Holm S. Accountablity for reasonableness: opening the black box of process. Healthcare Anal 2005;13:261-73.

46. Lauridsen S, Lippert-Rasmussen K. Legitimate allocation of public healthcare: beyond accountability for reasonableness. Public Health Ethics 2009;2:59-69.

47. Newell P, Bellour S. Mapping accountability: origins, contexts and implications for development. IDS Working Paper 168. Brighton: Institute for Development Studies, 2002:24.

48. Newell P, Wheeler J. Rights, resources and the politics of accountability: an introduction. In: Newell P, Wheeler J, eds. Rights, resources and the politics of accountability. London: Zed Books, 2006:1-36.

49. Paul S. Accountability in public services: exit, voice and control. World Dev 1992;20:1047-60.

50. Ackerman S. Co-Governance for accountability: beyond "Exit" and "Voice". World Dev 2004;32:447-63.

51. Kearns KP. Managing for accountability. Preserving the public trust in public and non-profit organizations. San Francisco: Jossey-Bass, 2010.

52. Frink D, Klimoski RJ. Advancing accountability theory and practice Introduction to the human resource management review special edition. Hum Resour Manag Rev 2004;14:1-17.

53. Moncrieffe J. Relational accountability. Complexities of Structural Injustice. London: Zed Books, 2011.

54. Daniels N. Accountability for reasonableness. BMJ 2000;321:1300-1.

55. Peters BG. Institutional theory. Problems and prospects. In: Pierre JB, Peters BG, Stoker G, eds. Debating institutionalism. Manchester: Manchester University Press, 2008:1-17.

56. Hirschman AO. Exit, voice and loyalty. Responses to decline in firms, organizations and states. Cambridge, MA: Harvard University Press, 1970

57. Roberts N. Keeping public officials accountable through dialogue: resolving the accountability paradox. Public Adm Rev 2002;62:658-68.

58. Schedler A, Diamond L, Plattner MF, eds. The self-restraining state. Power and accountability in New Democracies. Boulder, CO: Lynne Rienner, 1999.

59. Devas N, Grant U. Local government decision-making-citizen participation and local accountability: some evidence from Kenya and Uganda. Public Adm Dev 2003;23:307-16.

60. Behn RD. Rethinking democratic accountability. Washington DC: Brookings Institution Press, 2001.

61. Koppell J. Pathologies of accountability: ICANN and the challenge of "Multiple Accountabilities Disorder". Public Adm Rev 2005;65:94-108.

62. Gregory R. Accountability in modern government. In: Peters BG, Pierre J, eds. Handbook of public administration. London: Sage, 2003:557-68.

63. Dubnick M. Accountability and the promise of performance. Public Performance Manage Rev 2005;28:376-417.

64. Jaffee D. Organization theory. Tension and change. International edition ed. New York: McGraw-Hill, 2001.

65. Edwards M, Hulme M. NGO performance and accountability: introduction and overview. In: Edwards M, Hulme M, eds. Non-Governmental organisations-performance and accountability beyond the magic bullet. London: Earthscan, 1995:3-16.

66. Emanuel LL. A professional response to demands for accountability: practical recommendations regarding ethical aspects of patient care. Ann Intern Med 1996;124:240-9.

67. Najam A. NGO accounability: a conceptual framework. Dev Policy Rev 1996;14:339-53.

68. Ebrahim A. Accountability myopia: losing sight of organisational learning. Nonprofit Voluntary Sector Q 2005;34:56-87.

69. Roberts M, Hsiao W, Berman P, et al. Getting health reform right. A guide to improving performance and equity. Oxford, New York: Oxford University Press, 2004. 
70. WHO. Towards better leadership and management in health: report on an international consultation on leadership and management in low-income countries. Making health systems work. Geneva: World Health Organisation, 2007.

71. Schedler A. Conceptualizing accountability. In: Schedler A, Diamond $\mathrm{L}$, Plattner MF, eds. The self-restraining state power and accountability in new democracies. Boulder, CO: Lynne Rienner, 1999:13-28.

72. Gloppen S. Litigation as a strategy to hold governments accountable for implementing the right to health. Health Hum Rights 2008;10:21-36.

73. Berlan D, Shiffman J. Holding health providers in developing countries accountable to consumers: a synthesis of relevant scholarship. Health Policy Plan 2012;27:271-80.

74. Falisse JB, Meessen B, Ndayishimiye J, et al. Community participation and voice mechanisms under performance-based financing schemes in Burundi. Trop Med Int Health 2012;17: 674-82.

75. McNamara P. Provider-specific report cards: a tool for health sector accountability in developing countries. Health Policy Plan 2006;21:101-9.

76. Cornwall A, Lucas $\mathrm{H}$, Pasteur K. Introduction: accountability through participation: developing workable partnership models in the health sector. IDS Bulletin 2000;31:1-13.

77. Romzek BS, LeRoux K, Blackmar JM. A preliminary theory of informal accountability among network organizational actors. Public Adm Rev 2012;72:442-53.

78. Pellegrino ED. Towards a reconstruction of medical morality. $A m \mathrm{~J}$ Bioeth 2006;6:65-71.

79. Romzek BS, Dubnick MJ. Accountability in the public sector: lessons from the challenger tragedy. Public Adm Rev 1987;47:227-38

80. Bovens M, Schillemans T, Hart PT. Does public accountability work? An assessment tool. Public Adm 2008;86:225-42.

81. George A. 'By papers and pens, you can only do so much': views about accountability and human resource management from Indian government health administrators and workers. Int J Health Plann Manage 2009;24:205-24.

82. Goetz AM, Gaventa J. Bringing citizen voice and client focus into service delivery. IDS Working Paper. Brighton: Institute of Development Studies, 2001.
83. Goetz AM, Jenkins R. Hybrid forms of accountability: citizen engagement in institutions of public sector oversight in India. Public Manag Rev 2001;3:363-83.

84. Goetz AM, Jenkins R. Voice and accountability in service delivery. Dev outreach 2001;6:8-10.

85. Jenkins R, Goetz AM. Accounts and accountability: theoretical implications of the right-to-information movement in India. Third World Q 1999;20:603-22.

86. Lasker RD, Weiss ES. Broadening participation in community problem solving: a multidsciplinary model to support collaborative practice and research. J Urban Health 2003;80:14-47.

87. Boin A, McConnell A, Hart PT. Governing after crisis. The politics of investigation, accountability and learning. Cambridge: Cambridge University Press, 2008.

88. Bovens M. The Quest for Responsibility. Accountability and citizenship in complex organisations. Cambridge: Cambridge University Press, 1998.

89. Brown LD, Moore MH. Accountability, strategy and international nongovernmental organizations. Nonprofit Voluntary Sector $Q$ 2001;30:569-87.

90. Cornwall A, Coelho VSP. Spaces for change? The politics of participation in new democratic arenas. In: Cornwall A, Coelho VSP, eds. Spaces for change? The politics of participation in new democratic arenas. London: Zed Books, 2007:1-32.

91. Ebrahim A. Accountability in practice: mechanisms for NGOs. World Dev 2003;31:813-29.

92. Ebrahim A. Making sense of accountability: conceptual perspectives for northern and southern nonprofits. Nonprofit Manag Leadersh 2003;14:191-211.

93. Kilby P. Accountability for empowerment: dilemmas facing non-governmental organizations. World Dev 2006;34:951-963.

94. Koppell J. The politics of quasi-government. Hybrid organizations and the dynamics of bureaucratic control. Cambridge: Cambridge University Press, 2006.

95. Steets J. Accountability in public policy. Oxford: Oxford University Press, 2005

96. Mulgan R. Accountability. An ever-expanding concept? Public Adm 2000;78:555-73.

97. Ospina S, Diaz W, O'Sullivan JF. Negotiating accountability: managerial lessons from identity-based nonprofit organizations. Nonprofit Voluntary Sector Q 2002;31:5-31. 